Коробка I.М., командир, льотчик 1 класу САЗ ОРС, ДСНС Украӥни, м. Київ, ORCID: 0000-0002-5310-4917

Korobka I., Commander, 1st class pilot, Special Aviation Detachment of the Rescue Service, State Service of Ukraine for Emergencies, Kyiv

\title{
ОРГАНІЗАЦІЙНО-ПРАВОВІ МЕХАНІЗМИ ПУБЛІЧНОГО УПРАВЛІННЯ В СФЕРІ НАЦІОНАЛЬНОГО ЦИВІЛЬНОГО ЗАХИСТУ
}

\section{ORGANIZATIONAL AND LEGAL MECHANISMS OF PUBLIC ADMIN- ISTRATION IN THE FIELD OF NATIONAL CIVIL PROTECTION}

В статті визначено теоретичні та практичні питання циивільного захисту (ЦЗ) як об 'єкту системи публічного управління в Україні у частині використання організаційно-правового механізму державного управління та адміністрування в сфері иивільного захисту. Розкриті категорії та суспільні відносини в сфері управління ризиками надзвичайних ситуачій, зокрема досліджено теоретичні надбання та погляди науковців на стан і иілі системи (механізмів) управління в сфері цивільного захисту в Україні. В роботі комплексно з використанням сучасних методів пізнання, урахуванням новітніх досягнень науки державного управління досліджено теоретичні питання організаційно-правового забезпечення функціонування механізмів публічного управління та адміністрування. Обгрунтовано теоретичне розуміння змісту категорії «організаційно-правовий механізм», «иивільний захист» $i$ «публічне управління ризиками», а саме: обтрунтоване необхідність оновлення та модернізащії організаційно-правових механізмів публічного управління та адміністрування. Також в статті здійснено дослідження напрямів розвитку інституту ичивільного захисту в Украӥні та теоретично доведено щзо сучасною метою процесу вдосконалення дієвості ичивільного захисту є реформування та оновлення нормативно забезпечення децентралізованої управлінської моделі в сфері циивільного захисту в Украӥні.

Ключові слова: публічне та державне управління, иивільний захист, організаційно-правові механізми, суспільні відносини, управління та ризики.

The article identifies theoretical and practical issues of civil protection as an object of the public administration system in Ukraine in terms of the use of organizational and legal mechanism of public administration and administration in the field of civil protection. Categories and public relations in the field of emergency risk management are revealed, in particular, the theoretical achievements and views of scientists on the state and goals of the system (mechanisms) of management in the field of civil protection in Ukraine are studied. In the work complex with the use of modern methods of cognition, taking into account the latest achievements of the science of public admin- 
istration, theoretical issues of organizational and legal support of the functioning of mechanisms of public administration and administration are studied. Theoretical understanding of the content of the categories "organizational and legal mechanism", "civil protection" and "public risk management" is substantiated, namely the need to update and modernize the organizational and legal mechanisms of public administration and administration is substantiated. The article also studies the development of the institute of civil protection in Ukraine and theoretically proves that the current purpose of the process of improving the effectiveness of civil protection is to reform and update the decentralized management model in the field of civil protection in Ukraine.

Key words: public and public administration, civil protection, organizational and legal mechanisms, public relations, management and risks.

Постановка проблеми. Сучасне публічне управління та адміністрування функціонує в умовах підвищеної складності, невизначеності та динамічності навколишнього соціально-економічного середовища, зокрема в сфері цивільного захисту України. За таких умов слід враховувати роль організаційно-правових засобів (методів, інструментів) формування механізмів публічного управління та адміністрування в сфері цивільного захисту як важливого напрямку в процесі вдосконалення сучасного державного управління та регулювання, зокрема за складних умов світового та вітчизняного досвіду (практики) боротьби із CoViD-19.

Провідним і своєчасним питанням в нашій країні $\epsilon$ реальне вдосконалення системи цивільного захисту, попередження надзвичайних ситуацій $\mathrm{i}$ зниження масштабів матеріальних, соціальних та інших втрат від військових і інших дій на території України. Сьогодні, після активної фази військової агресії на землях України стало зрозумілим, що потребують оновлення організаційно-правові механізми публічного управління та адміністрування в сфері цивільної безпеки, зокрема за допомогою вчасного та дієвого використання новітніх організаційних і правих засобів їх розвитку та вдосконалення.

Аналіз останніх досліджень і публікацій. Серед вітчизняних і зарубіжних вчених, що зробили значний внесок у розв'язання проблем безпеки, слід відзначити В. Горбуліна, С. Пірожкова, Г. Почепцова, Г. Малинецького, В. Ярочкіна. Разом з тим дослідження в яких комплексно розглядались науково-теоретичні засади організаційно-правового забезпечення чи механізмів публічного управління, категорії чи відносини в сфері цивільного захисту, практично відсутні.

В контексті статті існують теоретичні дослідження, групи вчених П. Волянський, В. Воротін, С. Домбровська, С. Романенко, В. Садковий та ін., які справедливо роблять висновок, що сучасна ситуація в сфері цивільного захисту потребує оновлення законодавчого забезпечення та аналізу вже діючих нормативних актів в частині їх оновлення та модернізації [1].

Крім того, зовсім невирішеними $\epsilon$ суттєві питання розробки та 
функціонування організаційних механізмів державного регулювання в сфері цивільного захисту на регіональному рівні на засадах генезису ролі місцевого самоуправління, яке сьогодні виходить на перші роли в місцевому розвитку. Практично відсутні дослідження в сфері узагальнень світового досвіду використання моделі взаємодії органів публічної влади 3 усіма суб'єктами господарської діяльності для вирішення низки проблем ресурсного забезпечення системи управління на місцях.

Мета статті. В даній роботі поставлено за мету з'ясувати трактування категорій «організаційно-правовий механізм», «цивільний захист (ЦЗ)» в якості окремих управлінських категорій, визначення яких пов'язане 3 використанням сучасних механізмів і методів (інструментів) державного управління в національній практиці. Дослідити новітні теоретичні дослідження та позиції українських авторів щодо формування організаційно-правових механізмів (законодавства) в сфері ЦЗ за умов реформування всієї управлінської системи, зокрема в означеній сфері.

Виклад основного матеріалу. Напрями розвитку цивільного захисту в сучасних безпекових умовах Україні та організаційно-правовий механізм публічного (державного) управління в цій сфері відіграє значну роль, зокрема, стосовно попередження загроз і ризиків виникнення надзвичайних ситуацій. Такій підхід до формування дієвої системи цивільного захисту потребує вдосконалення за наступними напрямами:

- підвищення рівня стійкості функціонування економічних об’єктів у випадках настання та розвитку надзвичайних ситуацій;

- забезпечення профілактики наслідків щодо надзвичайних ситуацій та усунення їх негативних наслідків з матеріально-технічної й фінансової точки зору;

- розробка державної політики в сфері цивільного захисту відносно забезпечення функціонування національної системи з профілактики та реагування на випадки виникнення надзвичайних ситуацій;

- підвищення безпеки громадян і довкілля, профілактика настання та виникнення ситуацій надзвичайного характеру;

- формування державного нагляду та контролю за реалізацією заходів щодо підтримки безпеки громадян від випадків настання та розвитку надзвичайних ситуацій [2].

За сучасних умов господарювання функції та роль законодавчих (організаційно-правових) механізмів публічного управління щодо профілактичної практики усунення надзвичайних ситуацій та мінімізування їх наслідків $є$ визначальною. Ці механізми та притаманні їм інструменти дозволяють:

- здійснити розподіл професійного збору й обробки повної інформації з різних рівнів публічного управління надзвичайними ситуаціями;

- оптимізувати підходи до побудови дієвої системи підтримки прийняття рішень і узгодження ії з системою відповідальності за недотримання 
нормативно встановлених алгоритмів дій.;

- модернізувати взаємозв'язок суб'єктів експертної оцінки 3 діями посадовців, до повноважень яких входить державне управління у сфері цивільного захисту;

- визначити рівень і межі вільного (відкритого) пошуку інформації щодо прийняття посадовою особою рішень стосовно державного управління в сфері цивільного захисту;

- розмежувати функції, права й обов'язки представників державного управління стосовно означеної сфери цивільного захисту;

- здійснити раціональне встановлення часового навантаження, потрібного для впровадження державно-управлінських (публічних) функцій стосовно цивільного захисту [3].

На нашу думку, перш ніж безпосередньо розглядати організаційноправовий механізм державного управління в сфері цивільного захисту, зокрема, стосовно розвитку всісї системи захисту від ризиків настання та подолання наслідків надзвичайних ситуацій, доцільно розглянути парадигму чи дефініцію правового забезпечення самої системи публічного управлінського процесу.

Так, визначення правового (організаційно-правового) забезпечення управління уперше було зафіксоване в управлінській науці стосовно математичних і кібернетичних систем, які включали людину в свій склад як частину автоматизованої системи управління. А вже пізніше було надано визначення організаційно-правового забезпечення управління як засобу управління відносно визначеної суспільної сфери відносин, зокрема в сфері розвитку цивільного захисту в сучасних безпекових умовах.

Фактично є можливість визначити законодавче забезпечення управління в якості формування та підтримки основних характеристик організаційно-функціонального спрямування, які притаманні управлінським системам, через здійснення упорядкованого впливу всіх наявних законодавчо-нормативних засобів. Цей процес включає розробку, обговорення та прийняття таких нормативних документів.

У цілому, система правового забезпечення публічного (державного) управління надзвичайними ситуаціями, зокрема, загрозами та ризиками їх настання та розвитку, складається 3 сукупності законів і затверджених підзаконних нормативно-правових актів, які формують необхідне правове поле для забезпечення діяльності органів держави і життєзабезпечення населення в умовах настання та розвитку систем захисту від надзвичайних ситуацій [4].

У цілому, на нинішньому етапі розвитку національної господарської системи нормативно-правову базу сучасного державного управління 3 питань профілактики настання та навидь певних ознак надзвичайних ситуацій складають закони України, укази Президента України, постанови Кабінету Міністрів України тощо. Ми вже наводили повний перелік і не будемо цього 
робити в цій статті.

За умов розвитку України та оновлення процесів регулювання заходами профілактики надзвичайних ситуацій та дій у випадки їх настання та загроз їх розвитку здійснюється з урахуванням чіткого алгоритму та комплексно з правової точки зору. Переважно подібне управління та регулювання забезпечується та концентрується на галузях адміністративного, екологічного та трудового права.

Вважаємо завданням галузі науки державне управління, за необхідне, здійснити ретельний аналіз і моніторинг сучасних особливостей правової еволюції вітчизняного законодавства стосовно сфери цивільного захисту. Про це говорять експерти та фахівців в сфері цивільного захисту, зокрема йшла мова на XXI Всеукраїнській науково-практичній конференції (за міжнародною участю) «Розвиток цивільного захисту в сучасних безпекових умовах» 8 жовтня 2019 року в м. Києві, де автор приймав участь у якості організатора та учасника.

Відзначимо, що в процесі вирішення проблеми підтримки та забезпечення безпеки суспільних відносин і громадян з організаційно-правової точки зору провідні країни світу поступово вдосконалювали власне законодавство відносно надзвичайних ситуацій - від розробки та прийняття законодавства, що регулювали дії в умовах настання та розвитку конкретних випадків небезпек до ухвалення окремих законів, що регламентували загальні концептуальні дії [5].

Протягом останніх років в Україні було проведено багато заходів i зібрань, які були спрямовані на вдосконалено ідеології (концепції) державного управління в умовах надзвичайних ситуацій в контексті ії відкритості та публічності. Подібні заходи зумовлені тим, що питання безпеки та захисту населення, а також економічних і культурних об'єктів від настання та розвитку надзвичайних ситуацій нині сприймаються як складова державної безпеки з визнанням пріоритету саме цивільного захисту населення та територій від різнохарактерних загроз, що можуть виникнути протягом тривалого часу розвитку господарської системи, на відміну від вирішення проблем цивільної оборони, орієнтованої саме на воєнний час. Так, на нинішньому етапі розвитку економіки України, здійснюється пошук раціональної управлінської моделі забезпечення цивільного захисту з урахуванням дієвого та функціонального принципу реагування з боку держави на випадки настання та розвитку надзвичайних ситуацій замість використання звичайного галузевого принципу, який використовувалася раніше в цій системі.

Відзначимо, що сучасне формування системи державного цивільного захисту в Україні супроводжувався наявністю суттєвої кількості колізій законодавства, орієнтованого на регулювання надзвичайних ситуацій, а також фактичного функціонування децентралізованої системи прогнозування, профілактики, виявлення та нейтралізації надзвичайних ситуацій на державному рівні. 
У цьому контексті необхідно звернути увагу на прийняття ще в 2012 році Кодексу цивільного захисту, який нормативно регулює суспільні відносини, пов'язані з захистом населення, територій, навколишнього природного середовища та майна від надзвичайних ситуацій, реагуванням на них, функціонуванням єдиної державної системи цивільного захисту, та визначає повноваження органів публічної влади, органів місцевого самоврядування, права й обов'язки громадян України, іноземців та осіб без громадянства, підприємств, установ і організацій незалежно від форми власності [5].

Відзначимо, що прийняття Кодексу цивільного захисту України від 02.10.2012 № 5403-VI в цілому сформувало напрями діяльності та забезпечило низку таких переваг національної системи розвитку цивільного захисту в сучасних безпекових умовах: усунення дублюючих управлінських функцій органів публічної влади; уніфікація термінологічної бази нормативноправових актів стосовно цивільного захисту; кодифікація законодавства, що регулювало надзвичайні ситуації;

Важливо, що після введення в дію означеного Кодексу цивільного захисту відбувся перехід на більш дієву систему захисту, зокрема втратили чинність наступні закони: Закон України "Про аварійно-рятувальні служби"; Закон України "Про захист населення і територій від надзвичайних ситуацій техногенного та природного характеру"; Закон України "Про правові засади цивільного захисту"; Закон України "Про Цивільну оборону України"; Закон України "Про пожежну безпеку"; Закон України "Про загальну структуру і чисельність військ Цивільної оборони"; Закон України "Про війська Цивільної оборони України" [6].

На нашу думку, саме наслідком скасування зазначених Законів України, з'явилася низка питань, пов'язаних із необхідністю корегування та модернізації певних категорій, термінологічного апарату в сфері розвитку цивільного захисту в Україні. Ця проблема актуальна і сьогодні. У цьому контексті необхідно визначити, що в межах діючого організаційноправового механізму державного управління ризиками та загрозами виникнення надзвичайних ситуацій майже відсутні чіткі затверджені інструкції щодо виконання положень законодавчих i підзаконних нормативноправових актів стосовно попередження цих ризиків, а також відсутній дієвий управлінський механізм щодо контролю профілактики виникнення надзвичайних ситуацій [7]. У цьому випадку необхідно відмітити, що на нинішньому етапі розвитку системи цивільного захисту відсутнє чітке управлінське розмежування повноважень органів публічної влади та місцевого самоврядування щодо здійснення зазначених функцій в сфері цивільного в Україні.

Висновки. За умов існуючого законодавчого (організаційноправового) механізму державного управління розвитком цивільного захисту в сучасних безпекових умовах, ризиків надзвичайних ситуацій відсутні чіткі затверджені алгоритми дій щодо реалізації положень законодавчих і підза- 
конних нормативно-правових актів стосовно попередження цих ситуацій i ризиків, а також відсутній дієвий механізм щодо контролю профілактики виникнення надзвичайних ситуацій, що в сучасних умовах розвитку економіки України головним нормативно-правовим документом в цій сфері $\epsilon$ Кодекс цивільного захисту, який регулює всі суспільні відносини, пов'язані iз захистом населення, територій, навколишнього природного середовища та майна від випадків виникнення надзвичайних ситуацій, реагуванням на них, функціонуванням єдиної національної системи цивільного захисту. Розробка та прийняття означеного Кодексу дозволило усунути тільки частину прогалин та певне дублювання діючого законодавства в чистині розмежування управлінських повноважень і організаційних функцій центральних і місцевих органів виконавчої влади в сфері цивільного захисту.

Сучасний етап розвитку цивільного захисту вимагає подальшого реформування єдиної системи цивільного захисту в частині вдосконалення чинного законодавства, використання досвіду провідних країн щодо розвитку цивільного захисту, застосування новітньої технології реагування на надзвичайні ситуації, зміцнення потенціалу ОТГ у означених питаннях.

\section{Список використаних джерел:}

1. Дометрична допомога в умовах надзвичайних ситуацій : практичний посібник / П. Б. Волянський, С. О. Гур'єв, М. Л. Долгий. - Харків. : ФОП Панов A. M., 2016. - 136 c.

2. Vorotin V. Ye., Romanenko Ye. A., Shchokin R. G., Pivovarov K. V. (2018). Improving the organizational and legal mechanism of state economic management: the european experience for ukraine. Financial and credit activity: problems of theory and practice, 3 (26), - 368-376.

3. Кравців С. Я. Ризик-орієнтований підхід у державному регулюванні у сфері техногенної та пожежної безпеки / С. Я.Кравців, О. М. Соболь, А. Г. Коссе // Вісник Національного університету цииільного захисту України. Серія. Державне управління. - 2017. - Вип. 1 (6). - С. 336-341.

4. Воротін В. С., Проданик В.М. Від регуляторої політики до державноприватного партнерства в публічному секторі України / В.С. Воротін, В.М. Проданик / Наукові записки Інституту законодавства Верховної Ради України, 2019. - № 1. - C. 95-102.

5. Gaetani F. The Structure, Role and Mandate of Civil Protection in Disaster Risk Reduction for South Eastern Europe. South Eastern Europe Disaster Risk Mitigation and Adaptation Programme. Report International Centre on Environmental Monitoring Research Foundation (CIMA) / F. Gaetani, A. Parodi, F. Siccardi, D. Miozzo, E. Trasforini [Electronic source]. - Access mode to a resource: http://www.unisdr.org/preventionweb/files/ 9346_Europe.pdf.

6. Воротін В. С. Модернізація сфери освіти та науки як об'єкта державного управління: конкурентні переваги для України / В.С. Воротін / Наукові записки Інституту законодавства Верховної Ради України, 2017. - № 6. - С. 153 160.

7. Федорчак В.В. Механізми державного управління ризиками виник- 
нення надзвичайних ситуацій в Україні : автореф. дис. на здобуття наук. ступеня доктора наук спец. 25.00.02 - механізми державного управління / В.В. Федорчак 2018, - Харків, 2018. - 40 с.

\section{References:}

1. Volianskyi, P. B., Huriev, S. O., Dolhyi, M. L. (2016). Domedychna dopomoha $v$ umovakh nadzvychainykh sytuatsii [Pre-medical Emergency Aids]. Kharkiv: FOP Panov A. M. [in Ukrainian].

2. Vorotin, V. Ye., Romanenko, Ye. A., Shchokin, R. G., Pivovarov, K. V. (2018). Improving the organizational and legal mechanism of state economic management: the european experience for ukraine. Financial and credit activity: problems of theory and practice, 3 (26), 368-376 [in English].

3. Kravtsiv, S. Ya., Sobol, O. M., Kosse, A. H. (2017). Ryzyk-oriientovanyi pidkhid u derzhavnomu rehuliuvanni u sferi tekhnohennoi ta pozhezhnoi bezpeky [Riskoriented approach in state regulation in the field of technogenic and fire safety]. Visnyk Natsionalnoho universytetu tsyvilnoho zakhystu Ukrainy. Seriia. Derzhavne upravlinnia - Bulletin of the National University of Civil Protection of Ukraine. Series: Governance, 1(6), 336-341 [in Ukrainian].

4. Vorotin, V. Ye., Prodanyk, V.M. (2019). Vid rehuliatoroi polityky do derzhavno-pryvatnoho partnerstva $\mathrm{v}$ publichnomu sektori Ukrainy [From Regulatory Policy to Public-Private Partnership in the Public Sector of Ukraine]. Naukovi zapysky Instytutu zakonodavstva Verkhovnoi Rady Ukrainy - Scientific notes of the Institute of Legislation of the Verkhovna Rada of Ukraine, 1, 95-102 [in Ukrainian].

5. Gaetani, F. Parodi, A., Siccardi, F., Miozzo, D., Trasforini, E. (n.d.). The Structure, Role and Mandate of Civil Protection in Disaster Risk Reduction for South Eastern Europe. South Eastern Europe Disaster Risk Mitigation and Adaptation Programme. Report International Centre on Environmental Monitoring Research Foundation (CIMA). www.unisdr.org. Retrieved http://www.unisdr.org/preventionweb/files/9346_Europe.pdf [in English].

6. Vorotin, V. Ye. (2017). Modernizatsiia sfery osvity ta nauky yak obiekta derzhavnoho upravlinnia: konkurentni perevahy dlia Ukrainy [Modernization of the sphere of education and science as an object of public administration: competitive advantages for Ukraine]. Naukovi zapysky Instytutu zakonodavstva Verkhovnoi Rady Ukrainy - Scientific notes of the Institute of Legislation of the Verkhovna Rada of Ukraine, 6, 153-160 [in Ukrainian].

7. Fedorchak, V. V. (2018). Mekhanizmy derzhavnoho upravlinnia ryzykamy vynyknennia nadzvychainykh sytuatsii v Ukraini [Mechanisms of State Risk Management of Emergencies in Ukraine]. Extended abstract of Doctor's thesis. Kharkiv [in Ukrainian]. 